$576.8 .097 .5: 576.8 .098: 547.458$

細菌多糖類の抗原性に関する研究

\author{
第 2 編 \\ Proteus X19 菌多糖類の沈降反応之Weil-Felix \\ 反応の関係に就して

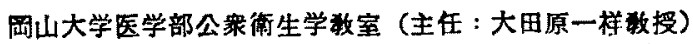 \\ 尃攻生横山衛 \\ [昭和 32 年 11 月 1 日受稿]
}

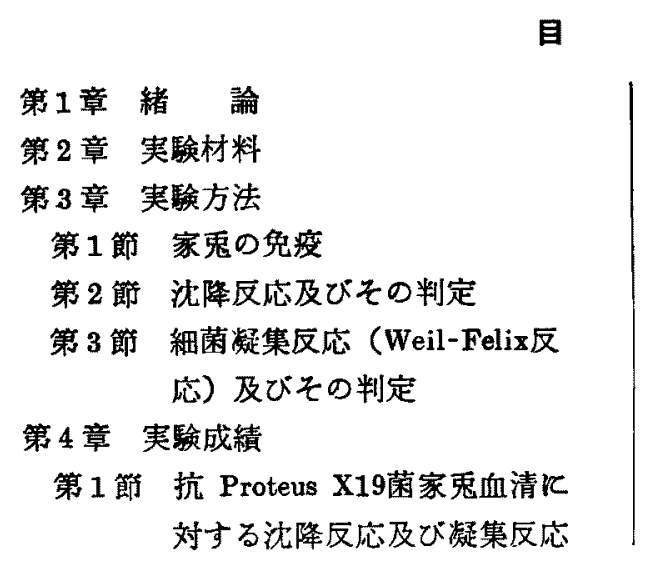

\section{第1車 粕論}

細菌多糖類が Hapten として，それ自身で 免疫した場合には抗体を作り得ないに拘らず， 細菌で免疫した抗体とは試駼管内に於て抗原 として作用する事は，脂炎双球菌についての Heidelberger 1), Avery ${ }^{2)}$ の実験以来幾多の 研究者によつて認められた事実である。

又, 発疹チフス及び発疹熱患者の血清と Proteus X19 菌とが凝集反応を呈することに よつて診断的価值を有する事は, Weil-Felix ${ }^{3)}$ の発見以来臨床的飞多く利用されている事柄 である.

Castaneda4)5)6) 等は Proteus X19 菌より含 水炭素系物質を抽出し，これと発疹チフス患 者血清との間に沈降反応の成立することを認 めた。 又, Bendich7) 等は三塩化醋酸法によ り抽出した多糖類を用いて発疹チフス患者血
次

第 2 節 発疹キフス及び発疹熱の既往 歴を有する者並びに発疹熱患 者の血清飞対する沈降反応及 び細菌凝集反応

第 3 節 沈降反応 (Uhlenhuth 氏法) 抗原価化对する Weil-Felix 反心凝集価の比較

第 5 章 考按

第 6 章 䋨覦

清と，同様に沈降反忘を行つている.

一方，黑屋8) 等は中性及び䣼性加熱法で抽 出した多糖類が，発疹チフス患者血清と沈降 反応を生じ，且つその価が Weil-Felix 反忍 の凝集価と平行する事を認め，领本9)等る同 粎の方法で両者の価が平行することを認めて Wる.

著者は，三塩化醋酸法を用いて Proteus X 19 菌多糖類を抽出し，これと Proteus X19 菌で免疫した家兔抗血清，発疹熱患者及び発。 疹チフス並びに発疹熱の既往歷を有する者の 血清との間に沈降反応を行い且つWeil-Felix 反応と対比して，興味ある関係を証明したの でここに報告する。

\section{第 2 龺 実酸材料}

（1）使用菌:

使用菌は岡山大学医学部微生物学教室保存 
の Proteus X19 菌の分与を受けて之を使用 した.

（2）動 物：

免疫のための動物は体重約 $3,000 \mathrm{gm} の$ 家 鬼を用いた。

（3）患者血清 :

現在発疹チフス及び発疮熱患者の発生が殆 んど見られないために，主として昭和19年よ り昭和和25年飞至る間飞既往歷を有する者及 び昭和30年に散発した発疹熱患者より得た血 清を実験に供した。

(4) Proteus X19 菌多糖類：

前記 Proteus X19 菌より三塩化酷酸抽出 法により第1編に於て述べた如く抽出精製し て使用した，精彆粉末は Biuret 反态陰性， Molisch 反応強陽性である。

\section{第3章実酫方法}

\section{第 1 節 家鬼の免淩}

前記 Proteus X19菌を試験管普通寒天斜面 培養基飞 $37^{\circ} \mathrm{C}, 20$ 㭙間培養し，その 1 斜面 を $10 \mathrm{cc}$ Ф生理的食塩水飞浮游せしめ，それ を $60^{\circ} \mathrm{C} ， 2$ 時間重湯前中で加温殺菌し，こ れを前記家鬼に 1 週間 2 回の間隔で第 1 回 $1 \mathrm{cc}$ ，第 2 回 $2 \mathrm{cc}$ ，第 3 回 $3 \mathrm{cc}$ ，以後 $3 \mathrm{cc}$ 宛 耳静脈内に注射乙，第16回注射後 3 日目飞全 採血してその血清を分離した（第16回注射後 家鬼の衰弱甚しきためやむなく 3 日目に全採 血を行つた）。血清には $1: 100 の$ Merthiolate をその $1 / 100$ 容量加えて保存した。

第 2 節 沈降反応及び其の判定

（1）沈降反応：

前述の方法によつて得た家鬼抗血清を抗体 とし，同しく前述の多糖類を抗原として抗原 抗体稀釈法 ${ }^{10}$ に上り沈降反忘を行つた。即ち 19\%ラビヤゴム生理的食塩水溶液を用いて 抗体を，生理的食塩水を用いて抗原を各々稀 釈し，これら抗原及び抗体を沈降反応用毛細 試験管內にて重層した。

患者血清は Uhlenhuth 氏法11飞より前述 の多糖類を抗原として沈降反応を行い抗原価 を検定した，抗原対照には生理的食壏水を。
抗体対照には正常家象血清を，患者血清飞対 する対照には健康人血清を使用した。

（2）反志の判定

抗原抗体を重層後接触面に白輸の生じたる のを陽性とし，重層後15分で陽性のるのを曲， 30 分卅，1 時間井，2 時間十を以て表し，然 らざるるのをーと記した。

第3 節 細菌凝集反応 (Weil-Felix 反応）及びその判定

前記 Proteus X19 菌を試験管普通寒天斜面 培基に $37^{\circ} \mathrm{C}, 20$ 時間培養し，との菌の 3 白金耳 $10.0 \mathrm{cc}$ の生理的食塩水飞浮游せ乙 めた後, $60^{\circ} \mathrm{C}$ の重湯煎中で 2 時間加温殺菌 する，次飞生理的食塩水を以て所定の稀釈度 飞稀釈した被検血清の各 $1.0 \mathrm{cc}$ K対し，乙 の菌浮游液を毛細ピベットを用いて各 4 滴宛 加古，上く振燙した後，2時間， $37^{\circ} \mathrm{C}$ 亿保 存して凝集の有無を検し，更飞24時間水室に 留置した後成績を判定した。

判定には肉眼及び Agglutinoscope を用い， 凝集の強さによって州，H，＋を以て表し， 反応陰性のものをーとした'2).

\section{第 4 草実䀫成綡}

第 1 節 抗 Proteus X19 菌家鬼血清 飞対する沈降反応及び凝集 反応

Proteus X19 菌多糖類と抗 Proteus X19 菌 家鬼血清との抗原抗体稀釈 法飞よる沈降反

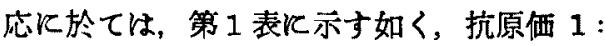

第1表沈降反応

Proteus X19 菌多糖類 $\rightarrow$ 抗 Proteus X19菌 家忽血清系

\begin{tabular}{|c|c|c|c|c|c|}
\hline 抗体稀秋 & $\vec{ت}$ & ?" & $\begin{array}{l}\stackrel{P}{=} \\
\ddot{-} \\
\rightarrow\end{array}$ & $\begin{array}{l}\text { S } \\
: \\
-1\end{array}$ & $\begin{array}{l}\text { 오 } \\
\ddot{-1} \\
-1\end{array}$ \\
\hline $1: \quad 1,000$ & H & WH & H & - & - \\
\hline $1: \quad 2,500$ & W & \# & \# & - & - \\
\hline 1. 5,000 & $H$ & 曲 & W & 州 & - \\
\hline 1. 10,000 & HI & 洲 & \# & HI & - \\
\hline $1: 25,000$ & H & H & \# & HII & - \\
\hline $1: 50,000$ & H & 册 & H\# & - & - \\
\hline $1: 100,000$ & - & - & - & - & - \\
\hline
\end{tabular}


50,000 , 抗体価 $1 ： 25$, 結合带抗原価 $1: 10,000$ であつた.

又, Proteus X19 菌と本抗血清との細菌凝 集反応は，第 2 表に示す如く，24時間值に於 て1:2,500の疑集価を示した。

第 2 表 細菌疑集反応 Proteus X19菌セ $\rightarrow$ 抗 Proteus X19菌 家鬼血清系

\begin{tabular}{|c|c|c|c|c|c|c|c|c|}
\hline 7 & 济积倍数 & & & & & & & 8 \\
\hline 時間 & & 요 & म․ & 品 & -i & is & is & 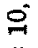 \\
\hline 梌体 & & -1 & 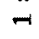 & - & $\ddot{r}$ & - & $\rightarrow$ & $\rightarrow$ \\
\hline & 2 時間 & + & + & \pm & - & - & - & - \\
\hline 抗 血 滑 & 24時間 & H & $\#$ & + & + & + & - & - \\
\hline 正常家鬼 & 2 㭙間 & - & - & - & - & - & - & - \\
\hline 血清 & 24時間 & \pm & \pm & - & - & - & - & - \\
\hline 理的 & 2 時間 & - & - & - & - & - & - & - \\
\hline & 24時間 & - & - & - & - & - & - & - \\
\hline
\end{tabular}

第2 節 発疹チフス及び発疹熱の既 往歴を有する者並びK発疹 熱患者の血清飞対する沈降 反応及び細菌凝集反応

第 3 表に示す如く，発疹チフスの既往歷を

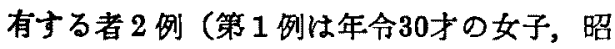
和 20 年12月満洲ハルピン市新香坊日本人收容 所飞於て罹患。第 2 例は年令 $41 才 の$ 男子，昭 和19年 2 月朝鮮咸鏡南道安辺郡安辺邑飞於て 䍜患) の血清飞対する沈降反応及び細菌凝集 反応 (Weil-Felix 反応) 次，次の如くであ る. 即ち，第 1 例（䧹患後10年を経過）飞於 ては Uhlenhuth 氏価 I:2,500, 凝集価 I： 500 を示した．又，第 2 例（罹患後11年を経 過）飞於ては，Uhilenbuth 氏価 $1: 500$, 凝 集価 1:250を示した。対照例（健康者）飞 於て社, Uhlenhuth 氏価 $1: 100$, 凝集価 1 :

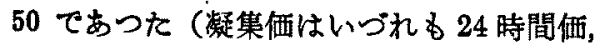
以下同様)，又，第 4 表飞示す如く，発疹熱 の既往歴を有する者（5例）の血清に対する 沈降反応及び細菌凝集反忘では，第 1 例（罹 患後 6 年を释過也る者)队於ては, Uhlenhuth 氏価 $1: 250$ ，疑集価 $1: 100$ を示し，第 2 例（署患後 5 年を経過せる者）飞於ては,
第 3 表 発疹チフスの既往歴を有する血 清の沈降反応及び凝集反応

1）沖○妙○？30才昭和20年12月犀患 沈降反心 (Ohlenhuth)

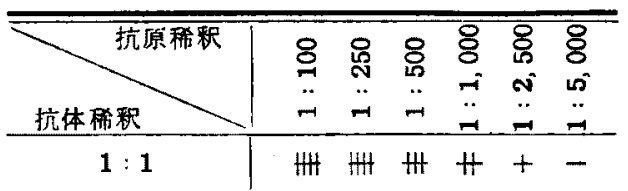

細菌频集反底

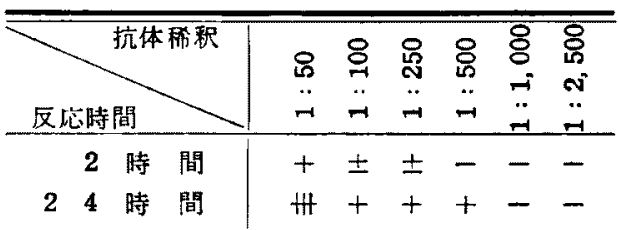

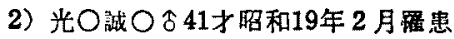
沈降反心 (Uhlenhuth)

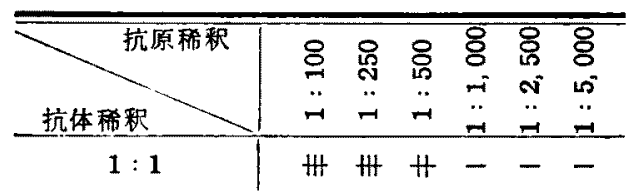

紐菌凝集反応

\begin{tabular}{l}
\hline 反抗体杼秎 \\
\hline
\end{tabular}

対 照

井○ア○ミ웅

沈降反店 (Uhlenhuth)

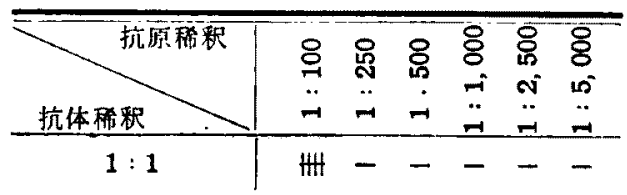

糿藏凝集反沁

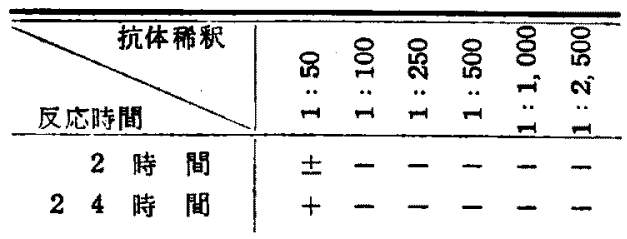

Uhlenhuth 氏価 1:250, 凝集洒 1：100を 示し，第 3 例（㭢㭧後 5 年を経過せる者）反 於ては, Uhlenhuth 氏価 $1: 500$, 凝集価 1 : 
第 4 表 発疹熱の既往歴を有する血清の 沈降反応及び凝集反応

1) 今○峰○早30才昭和 24 年 11 月露患 沈降反心 (Uhlezhuth)

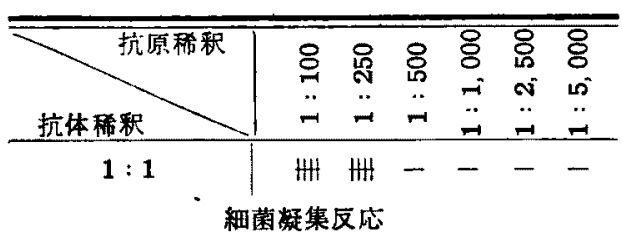

\begin{tabular}{|c|c|c|c|c|c|c|c|c|}
\hline 反心 & 時間 & & $\begin{array}{l}80 \\
\ddot{n} \\
-1\end{array}$ & $\begin{array}{l}8 \\
\stackrel{9}{7} \\
-1\end{array}$ & $\begin{array}{l}\text { 品 } \\
\because \\
- \\
-\end{array}$ & \begin{tabular}{l}
8 \\
\hdashline \\
-1
\end{tabular} & $\begin{array}{l}8 \\
8 \\
- \\
- \\
-\end{array}$ & 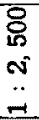 \\
\hline & 2 㭙 & 間 & - & - & - & - & - & - \\
\hline 2 & 4 㭙 & 間 & $H$ & + & - & - & - & - \\
\hline
\end{tabular}

2) 波O野O太古47才昭和25年12月慨患 沈降反心 (Uhlenhuth)

\begin{tabular}{|c|c|c|c|c|c|}
\hline 抗体稀釈 & 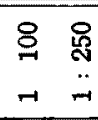 & $\begin{array}{l}8 \\
\\
-1\end{array}$ & : & $\begin{array}{l}8 \\
\text { L } \\
\text { N } \\
- \\
-1\end{array}$ & $\begin{array}{l}8 \\
\text { in } \\
?\end{array}$ \\
\hline $1: 1$ & H H & \pm & - & - & - \\
\hline
\end{tabular}

細菌凝集反応

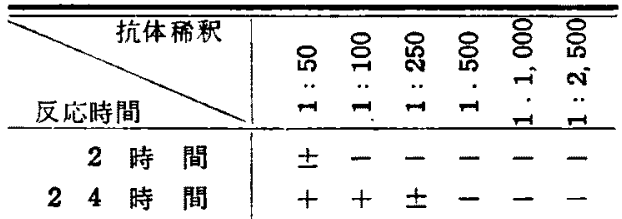

3）北○鹤○車29才昭和25年12月䅡患 沈降反心 (Uhlenhuth)

\begin{tabular}{|c|c|c|c|c|c|}
\hline 抗体桥积 & \begin{tabular}{ll}
8 & 0 \\
\hdashline & $\stackrel{0}{3}$ \\
$\because$ & $\because$ \\
- & -1 \\
\end{tabular} & $\begin{array}{l}8 \\
: 0 \\
\ddot{7} \\
-\end{array}$ & $\begin{array}{l}8 \\
\therefore \\
-1 \\
-1\end{array}$ & 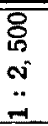 & $\begin{array}{l}8 \\
8 \\
15 \\
\because \\
-1\end{array}$ \\
\hline $1: 1$ & $\begin{array}{l}\text { 卅 州 } \\
\text { 踓反集反 }\end{array}$ & 世 & - & - & - \\
\hline
\end{tabular}

\begin{tabular}{|c|c|c|c|c|c|c|c|c|}
\hline 反応 & 寺間 & & $\begin{array}{l}8 \\
\ddot{n} \\
\ddot{-}\end{array}$ & $\begin{array}{l}\stackrel{8}{-} \\
\ddot{-} \\
- \\
\end{array}$ & $\begin{array}{l}\stackrel{8}{\leftrightarrow} \\
\stackrel{-}{-} \\
-\end{array}$ & $\begin{array}{l}8 \\
\stackrel{8}{\circ} \\
\ddot{-} \\
\end{array}$ & $\begin{array}{l}8 \\
8 \\
-1 \\
-1\end{array}$ & $\begin{array}{l}8 \\
\text { th } \\
\text { o }\end{array}$ \\
\hline & ２時 & & - & - & - & - & - & - \\
\hline 2 & ） 時 & 間 & + & + & + & - & - & - \\
\hline
\end{tabular}

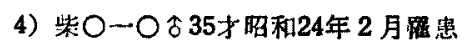
沈降反心 (Uhlenhuth)

\begin{tabular}{|c|c|c|c|c|}
\hline 抗体称积 & $\begin{array}{ll}\stackrel{8}{0} & \stackrel{8}{\circ} \\
\ddot{-} & \stackrel{-}{-}\end{array}$ & $\begin{array}{l}8 \\
\text { : } \\
-\end{array}$ & 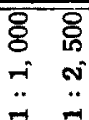 & $\begin{array}{l}8 \\
8 \\
6 \\
-7 \\
-10\end{array}$ \\
\hline $1: 1$ & $\mathrm{HWH}$ & - & $-\quad-$ & - \\
\hline
\end{tabular}

細菌凝集反応

\begin{tabular}{|c|c|c|c|c|c|c|c|c|}
\hline 反心 & 待間 & & $\begin{array}{l}80 \\
- \\
-\end{array}$ & $\stackrel{8}{8}$ & $\begin{array}{l}\text { 号 } \\
\stackrel{5}{ } \\
\ddot{-}\end{array}$ & $\begin{array}{l}8 \\
8 \\
\ddot{8} \\
-1\end{array}$ & $\begin{array}{l}8 \\
8 \\
- \\
\ddot{-1} \\
\end{array}$ & $\begin{array}{l}8 \\
\text { : } \\
\text { * } \\
\ddot{*} \\
\end{array}$ \\
\hline & 2 & 間 & \pm & - & - & - & - & - \\
\hline 2 & 4 & 間 & $\#$ & + & \pm & - & - & - \\
\hline
\end{tabular}

5）晹○元○合54才昭和25年 2 月羅患

沈降反㤁 (Uhlenhuth)

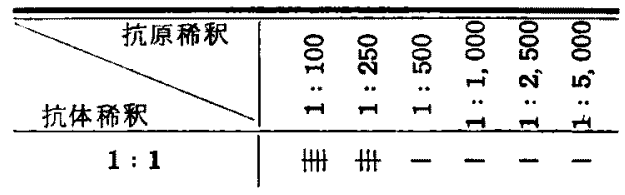

細菌凝集反応

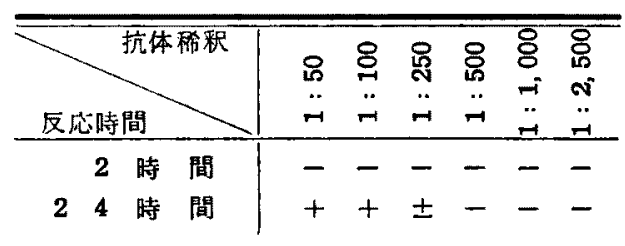

效 照

土○保○ 우 31

沈降反心 (Uhlenhuth)

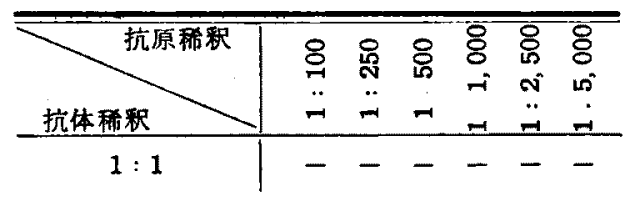

細菌凝集反心

\begin{tabular}{|c|c|c|c|c|c|c|c|c|c|}
\hline 反瓜 & Ang & & & $\begin{array}{l}\text { 号 } \\
\ddot{-} \\
-\end{array}$ & $\begin{array}{l}8 \\
\ddot{8} \\
\ddot{-}\end{array}$ & $\begin{array}{l}\text { 怘 } \\
\text { ज. } \\
-1\end{array}$ & $\begin{array}{l}8 \\
8 \\
\ddot{*} \\
- \\
\end{array}$ & $\begin{array}{l}8 \\
8 \\
- \\
- \\
-\end{array}$ & $\begin{array}{l}8 \\
8 \\
0 \\
\text { N } \\
\ddot{0} \\
-0\end{array}$ \\
\hline & 2 & 㭙 & 間 & - & - & - & - & - & - \\
\hline 2 & 4 & 時 & 間 & - & - & - & - & - & - \\
\hline
\end{tabular}

250 ，第 4 例（䍜患後 6 年を経過せる者）下 於ては, Uhlenhuth 氏価 $1: 250$, 凝集価 1 : 100 ，第 5 例（䍜患後 5 年を経過せる者）火 於ては, Uhlenhuth 氏価 $1: 250$, 凝集価 1： 100 を示した. 対照例では, 沈降反応は抗原 稀釈 1100 , 凝集反忘は抗体稀喽 1:50 K 於ていづれる陰性であつた。

又，第 5 表仁示す如く，発疹愁患者（3 例） の血清に対する沈降反忘及び細菌凝集反応 では，第 1 例（発病後 7 日）飞於ては， Uhlenhuth 氏価 $1: 1,000$, 凝集価 $1: 500$, 
第 5 表 発疹熱患者血清の沈降反応及び 凝集反応

1）横O伊O松合 49 才昭和 30 年 10 月露患 発病 後 7 日

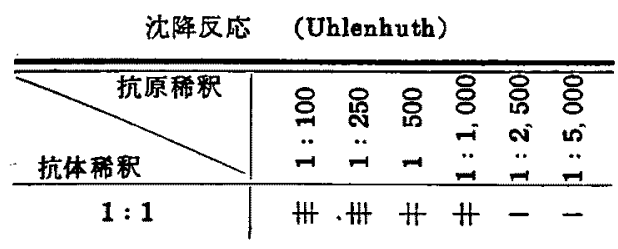

細菌烧集反心

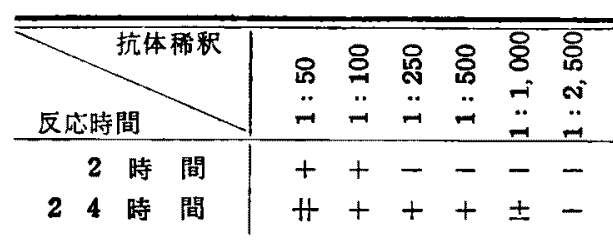

2) 碓O千O万46才昭和30年10月羅患発病後 6 日

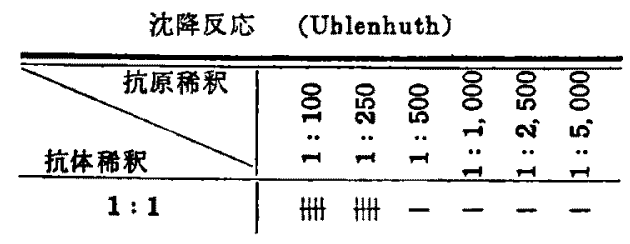

細菌疑集反応

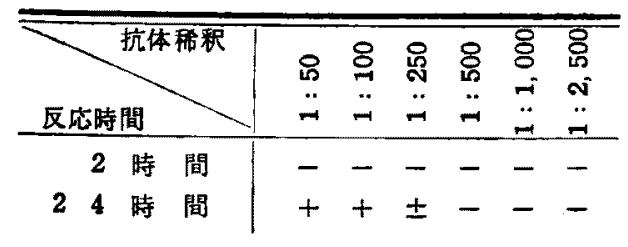

3）柴○四○合18才昭和30年10月墨患 発苪後

6 日

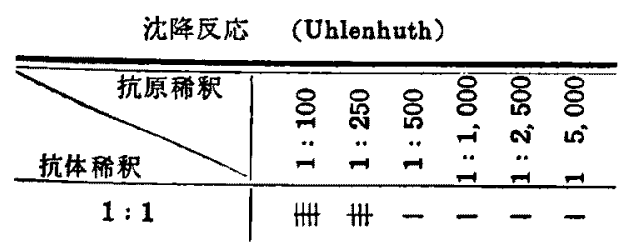

細菌数集反応

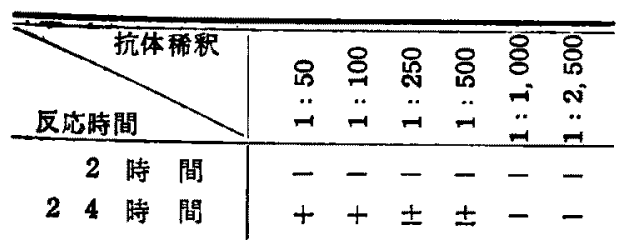

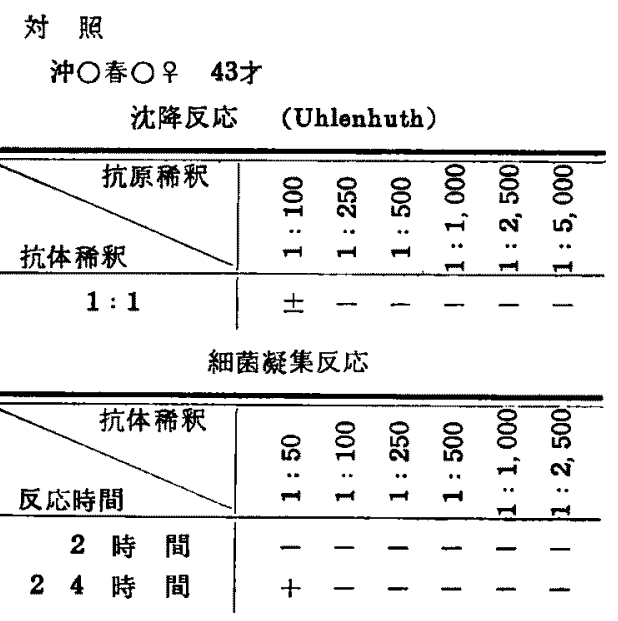

第 2 例（発病後 6 日）飞於ては, Uhlenhuth 氏価 $1: 250$, 凝集価 $1: 100$, 第 3 例（発病 後 6 日) 飞於ては, Uhlenhuth 氏価 $1: 250$, 凝集価 1：100 を示した。対照例於ては, Uhlenhuth 氏価 1:100(疑陽性), 凝集価 1:50を示した.

\section{第3 節 沈降反応 (Uhlenhuth 氏法) 抗原価住対するWeil-Felix 反応凝集価の比較}

上述の沈降反态及び凝集反心の成績を得た 結果，第 6 図に示す如く、横軸に凝集価を求 め, 领軸反 Ublenhuth 氏価を求めて, 両者 を比較するに，両者は平行関係にある事を認 め得た。

第6四沈降反忍 (Uhlenhuth) 飞対す る凝集反心比輘関保図

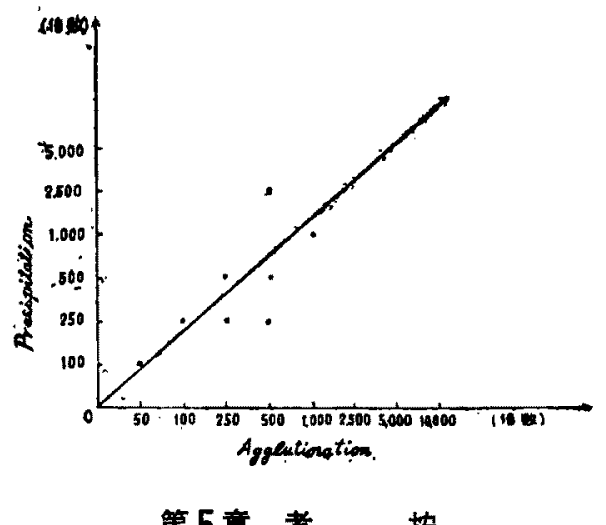

黒晊8) 等は中性及び酸性加熱法で抽出した 
本菌多糖類と発病後20～85日の間の発疮チフ ス患者血清との間飞沈降反忘を行い，1： 1,000 乃至 $1: 4,000,000$ の抗原価を認め, 又, 同一患者の発病後の時期による反応の程 度を比較して，発病後40日乃至50日に於て最 む高い抗原価を示し，70日以上経過すれば 1:5,000 乃至 $1: 1,000$ 飞低下すると述へ ている.

著者の場合は，このような血清が得られな かつたが，発疹チフス及び発疹熱の既往歴に よつて入手した血清を主とし，又，発病後 1 週間前後の血清を併せて検したのであつて， 当然その抗原価は低いけれど，䍜患後 5 〜 10 年にして 1:250 乃至 1:2,500 の抗原価を 認め, 又, 発病後 $6 \sim 7$ 日にして $1: 250$ 乃 至 $1: 1,000$ の抗原価を認め得た事は興味あ る事実と思われる。然して，本多糖類は抽出 飞当つて加熱除蛋白操作がないために，その 抗原性が比較的損われない状態にあると思わ れ，かつ前編に於て述へた如く，抽出收量及 び純度共秀れているので，多糖類抗原として 充分使用江耐え得るすのと思了。

\section{第 6 章 結論}

三塩化醋酸法により抽出した Proteus X19 菌多糖類を用いて，抗 Proteus X19 菌家鬼 血清, 並びに発疹熱息者, 発疹チフス及び発

\section{主 要 文 献}

1) Heidelberger, Goebel, Avery: J. Exp. Med., 42, 701, 1925.

2) \#eidelberger, Goebel, Avery : J. Exp. Med., 42, 727, 1925.

3) Weil-Folix : Wien. Klin. Wochenschr., Nr. 2, s. 29, 33, 927, 1916.

4) Zinsser, Castaneda: J. Exp. Med., 56, 455, 1932.

5) Castaneda, Zia: J. Exp. Med., 58, 55, 1933.

6) Castaneda: J. Exp. Med., 60, 119, 1934.

7) Bendich, Chargaff : J. Biol. Chem., 168, 283, 1946.
疹熱の既往歷を有する者の血清との間に, 沈 降反応を行い，かつ同時に行つた Weil-Felix 反応と此较して，次の如き成績を得た。

（1）抗 Proteus X19 菌家鬼血清との抗原 抗体稀釈法による沈降反応では，抗原価 1 : 50,000 , 抗体価 $1: 25$, 結合带抗原価 1 : 10,000であり, 細菌凝集反応による疑集価 は $1: 2,500$ であつた.

（2）発疹キフス及び発疹熱の既往歷を有 する者には抗体が残存し，その血清との沈降 反心では，抗原洒は 1:250 万至 1:2,500で あり，Weil-Felix反応による凝集価は1：100 乃至 1:500 であつた.

又，発疹熱患者血清との沈降反応の抗原価 は, 1:250 乃至 1:1,000であり，その細 菌凝集価は，1：250 乃至 1：1，000であつ た.

（3）沈降反忍抗原伍とWeil-Felix 反応 凝集価は平行関係を有する。

（4）本多糖類は長期保存が可能な特嶉を 有する.

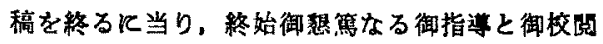
を睗つた恩師大田原敏授飞深謝するとともに，種れ

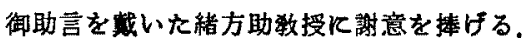

（本論文の要旨は昭和30年11月第65回岡山医学会総 会，及び昭和31年 4 月第26回日本衛生学会総会飞於 て発表した)

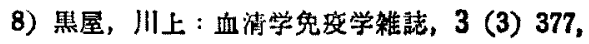
昭和17年。

9) 烊本, 吉沢:日本細菌学雜誌，1 (2) 241 , 昭 和19年.

10) Ogata: Z. f. Immunität Forschnung, Org. Bd. 39, 270, 1924 .

11) Uhlenhuth: Prkt. Anloitung $Z$ ur Ausführung biologischer Eiweissdifferenzierung, (Jena) 1909.

12）緒方：血清学実験法 (その手住どきから)，南山 堂药店，昭和19年。 


\title{
Studies on the Antigenicity of Bacterial Polysaccharides
}

Part 2:

\section{On the Relationship Between Precipitation by B. Proteus X19 Polysaccharide and Weil-Felix Reaction}

\author{
By \\ Mamoru Yokoyama \\ Department of Public Health Okayama University Medical SchooI \\ (Direcor: Prof. Dr. K. Ohtahara)
}

With the use of polysaccharide of B. Proteus X19 extracted by trichloracetate method, the author has performed precipitation between this polysaccharide and anti-serum of the rabbit immunized with Proteus X19 on one hand, and this polysaccharide against serum of Febris exanthematicus patient and serum of those having anamnesis of typhus exanthematicus and Febris exanthematicus on the other hand; and comparing these results with those with WeilFelix reaction performed concomitantly, the following results have been finally obtained.

1) In the precipitation with anti-Proteus $X 19$ rabbit serum by antigen-antibody-dilution method, various values have been found to be: antigen titer, 1:50,000; antibody titer, $1: 25$; and antigen titer of binding zone, $1: 10,000$; while the agglutination titer has been $1: 2,500$.

2) Antibody has remained in those patients having anamnesis of typhus exanthematicus or Febris exanthematicus. In the precipitation with their serum antigen titer has been found to be $1: 250-1: 2,500$; while the agglutination by Weil-Felix reaction has been $1: 100-$ $1: 500$.

Furthermore, in the precipitation with serum of Febris exanthematicus patient antigen titer has been fonnd to be $1: 250-1: 1,000$; while the agglutination titer is $1: 250-1: 1,000$.

3) The antigen titer of precipitation runs parallel to the agglutination titer of Weil-Felix reaction.

4) This polysaccharide seems to possess a special feature which makes it possible to be kept for a long period of time. 